\title{
NEW GYMNAMOEBAE SPECIES (GYMNAMOEBIA) IN THE FAUNA OF UKRAINE
}

\author{
M. K. Patsyuk \\ Franko Zhytomyr National University \\ B. Berdychiv str., 40, Zhytomyr, 10008 Ukraine \\ E-mail: kostivna@ukr.net
}

Received 10 November 2010

Accepted 28 March 2012

\begin{abstract}
New Gymnamoebae Species (Gymnamoebia) in the Fauna of Ukraine. Patsyuk M. K. - Information is given on new in the fauna of Ukraine gymnamoebae species: Saccamoeba stagnicola Page, 1974; Mayorella sp.; Korotnevella sp.; Paradermamoeba levis Smirnov et Goodkov, 1994; Paradermamoeba valamo Smirnov et Goodkov, 1993 and Stenamoeba stenopodia Smirnov, Nassonova, Chao et CavalierSmith, 2007.
\end{abstract}

Key words: fauna, Zhytomir Polissya, gymnamoebae.

Новые для фауны Украины виды голых амёб (Gymnamoebia). Пацюк М. К. - Приведены сведения об обнаружении новых для фауны Украины голых амёб: Saccamoeba stagnicola Page, 1974; Mayorella sp.; Korotnevella sp.; Paradermamoeba levis Smirnov et Goodkov, 1994; Paradermamoeba valamo Smirnov et Goodkov, 1993; Stenamoeba stenopodia Smirnov, Nassonova, Chao et CavalierSmith, 2007.

Ключевые слова: фауна, Житомирское Полесье, голые амёбы.

\section{Introduction}

Lobose gymnamoebae (representatives of the subclass Gymnamoebia Haeckel, 1862, class Lobosea Carpenter, 1861) inhabit almost all water and soil biotopes. However, because of difficulties in the species identification, fauna of these protists in many areas, including Ukraine, is almost unstudied till now. In a few papers from XIX-XX centuries there are scant fragmentary data on gymnamoebae found in this region (Stepanov, 1885; Vysotskiy, 1885; Pereyaslavtseva, 1886; Butchinskiy, 1897; Dobrovlyanskiy, 1914; Krasheninnikov, 1925; Fadeev, 1929). The works of M. P. Bozhko (1936, 1937) on soil gymnamoebae with 19 recorded species of these protists also worth to be mentioned (cited by Lepinis et al., 1973). In our previous studies we found 10 species of gymnamoebae (Patsuyk, 2010). In general, only 22 species are mentioned for Ukraine in literature. It is absolutely clear that representatives of the subclass Gymnamoebia need special comprehensive study using the up-to-date research methods applied for amoeboid organisms.

\section{Material and methods}

Materials were collected in September - November 2009, and in April - August 2010 in 75 localities of Zhytomir Polissya. Samples (water and roiled bottom sediments) were collected by hand with glass vessel and transported to laboratory. Totally 150 samples were collected.

During sampling, the following parameters were measured: active reaction of medium $(\mathrm{pH})$ with laboratory $\mathrm{pH}$-meter $(\mathrm{pH}-150 \mathrm{M})$, temperature of water $\left({ }^{\circ} \mathrm{C}\right)$, content of oxygen $(\mathrm{mg} / \mathrm{l})$ dissolved in water (Stroganov, 1980).

Amoebae were cultivated in Petri dishes on non-nutrient agar by Page technique (1988). Protozoans were studied under light microscope Zeiss Axio Imager M1 (Center of collective using of scientific equipment "Animalia" at Schmalhauzen Institute of Zoology NAS of Ukraine) with differential interference contrast. Amoebae were identified in two steps: first, their morphotype was determined (with the aid of respective keys: Smirnov and Goodkov, 1999; Smirnov and Brown, 2004; Smirnov, 2008); then (if available data allowed) Page taxonomic key (1988) and later publications on gymnamoebae taxonomy were used (Smirnov et al., 2007; Smirnov, 2008). 


\section{Results and discussion}

In Zhytomir Polissya we found 6 gymnamoebae species not revealed earlier in Ukraine.

Class LOBOSEA Carpenter, 1861

Subclass GYMNAMOEBIA Haeckel, 1862

Order EUAMOEBIDA Lepsi, 1960

Family HARTMANNELLIDAE (Volkonsky, 1931) Page, 1974

Saccamoeba stagnicola Page, 1974

Family PARAMOEBIAE (Poche, 1913) Page, 1987

Mayorella sp.

Korotnevella sp.

Family THECAMOEBIDAE (Schaeffer, 1926) Smirnov and Goodkov, 1994

Paradermamoeba levis Smirnov et Goodkov, 1994

Paradermamoeba valamo Smirnov et Goodkov, 1993

Stenamoeba stenopodia Smirnov, Nassonova, Chao et Cavalier-Smith, 2007

Genus Saccamoeba (Frenzel, 1892) Bovee, 1972

Locomotor stages of all amoebae from the genus Saccamoeba belong to monotactic morphotype. These are monopodial amoebae of limax type with elongated wormlike or clavate cell body. In anterior end of locomotor specimens there is a small characteristic crescent-like zone of hyaline cytoplasm. Uroid structures of knob-villous type are covered with small "setae" or "papillae". There is one nucleus of vesicular type. Bipyramidal cytoplasmic crystals are present. Some species form cysts.

The genus includes seven species, six of them were found in fresh waters (Smirnov, 2008). We found one species from the genus Saccamoeba - S. stagnicola Page, 1974.

\section{S. stagnicola Page, 1974 (fig. 1)}

Cell is elongated, worm-like, slightly bent when moving on substrate. Body length is $45-68 \mu \mathrm{m}$, width is $11-18 \mu \mathrm{m}$, length-width ratio $(\mathrm{L} / \mathrm{B})-4$. Frontal hyaline zone is poorly expressed. One contractile vacuole immediately near uroid is present. Uroid is convex, villous type. Diameter of nucleus is $4.3-6.0 \mu \mathrm{m}$. No significant cytoplasmic
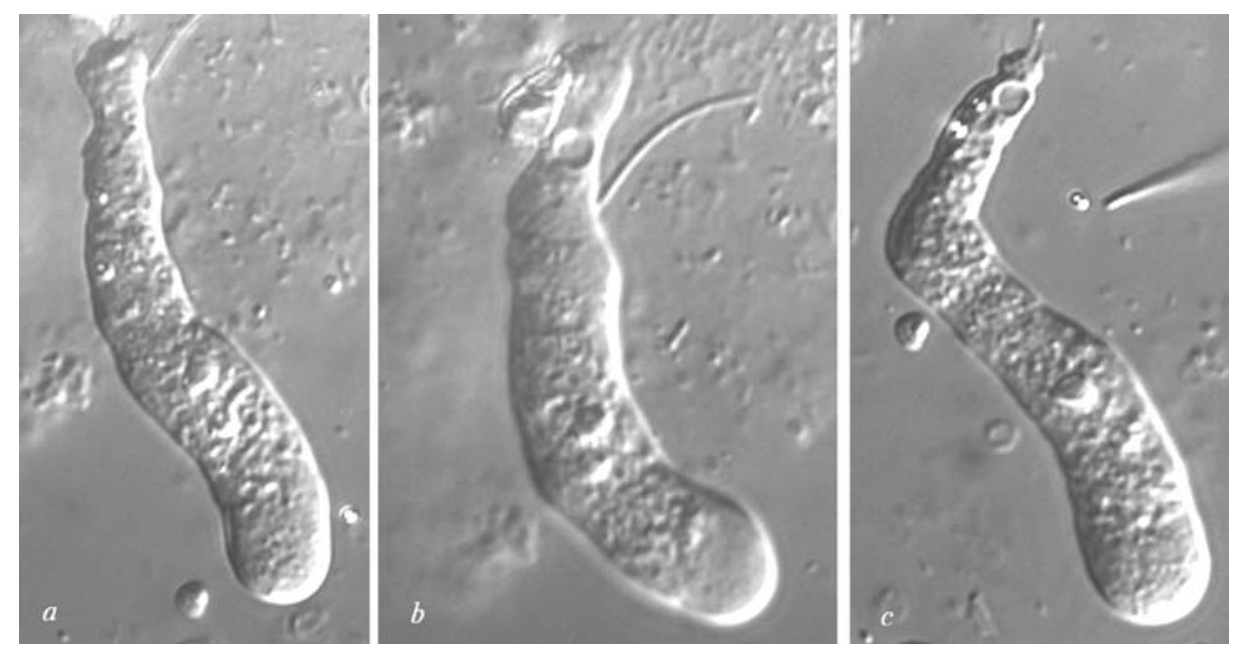

Fig. 1. Saccamoeba stagnicola, locomotor forms ( $a, b, c) . \times 1240$.

Рис. 1. Saccamoeba stagnicola, локомоторные формы $(a, b, c)$ х1240. 
crystals characteristic for other saccamoebae were revealed in cells. Amoebae of this species can form cysts, however, we did not see them in cultures.

Location: amoeba was found in lakes with sandy bottoms near the village Chernyavka of Krasnoarmeyskiy district ( $\mathrm{t}$ of water $-14{ }^{\circ} \mathrm{C}, \mathrm{pH}=8.62$, oxygen dissolved in water $8.06 \mathrm{mg} / \mathrm{l}$ ), v. Halchyn of Berdychiv district ( $\mathrm{t}$ of water $-17^{\circ} \mathrm{C}, \mathrm{pH}=$ 7.35 , oxygen dissolved in water $6.12 \mathrm{mg} / 1$ ), and $\mathrm{v}$. Pedynka of Lyubarsky district ( $\mathrm{t}$ of water $-22{ }^{\circ} \mathrm{C}, \mathrm{pH}=8.29$, oxygen dissolved in water $8.35 \mathrm{mg} / \mathrm{l}$ ).

Genus Mayorella (Schaeffer, 1926) Page, 1983

Locomotor stages of all Mayorella species belong to very specific mayorellian morphotype characteristic for species of this genus only. These amoebae generally have few relatively short conical obtuse hyaline subseudopodia of almost the same length normally produced from the frontal hyaline cytoplasm zone; subseudopodia may be temporarily absent in intensively moving individuals of some species. The nucleus in all Mayorella species is of vesicular type with one large nucleolus. There are also cellular ultrastructural characteristics in this genus: outer membrane has strongly developed supermembrane complex (100 $\mathrm{nm}$ thick) including rather discrete space-organized cylindrical or prismoidal elements perpendicular to body surface and immersed in solid fibrillar matrix (Goodkov, Buryakov, 1988). Six species of freshwater Mayorella are known (Smirnov, Brown, 2004; Smirnov, 2008).

Mayorella sp. (fig. 2)

An amoeba found is of mayorellian morphotype, so it can unequivocally be the representative of genus Mayorella. This amoeba forms small characteristic hyaline conical subseudopodia ( 1 to 3 ) on anterior end of the cell body. Protist moves rather slowly. With increased speed of movement, amoeba's body stretches and narrows toward the posterior end, and cell becomes triangular. Expressed uroid structures were not observed. The length of locomotor forms is $90-110 \mu \mathrm{m}$, width is $45-60 \mu \mathrm{m}, \mathrm{L} / \mathrm{B}$ ratio $=2.5-3.6$. One nucleus is $3.0-3.6 \mu \mathrm{m}$ in diameter. According to all these characters, this amoeba is closest to the freshwater species $-M$. cantabrigiensis, $M$. verspertilioides or $M$. penardi, however available data are insufficient for exact species identi-
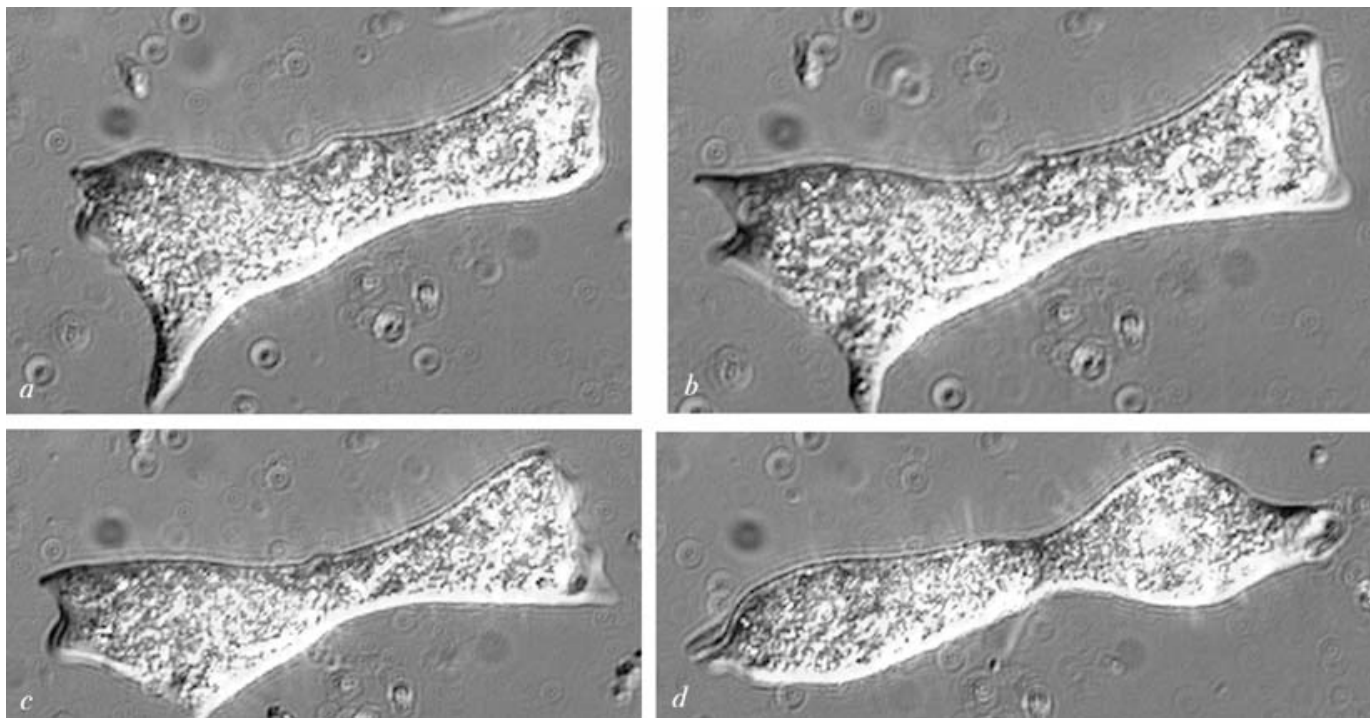

Fig. 2. Mayorella sp., locomotor forms $(a, b, c, d)$. x1240.

Рис. 2. Mayorella sp., локомоторные формы $(a, b, c, d)$. х1240. 
fication; in particular, there is no information on the ultrastructural organization of the cell cover.

Location: this species was found in rivers with sandy bottoms: r. Sedovka near v. Seleznevka, and r. Noryn near v. Lysyvin of Ovrooch district ( $\mathrm{t}$ of water $-9{ }^{\circ} \mathrm{C}$, $\mathrm{pH}=6.85$, oxygen dissolved in water $8.35 \mathrm{mg} / 1$ and $\mathrm{t}-12{ }^{\circ} \mathrm{C}, \mathrm{pH}=7.84$ oxygen dissolved in water $6.41 \mathrm{mg} / 1$, respectively), r. Mohylyanka near v. Brazhechka of Chernahivskiy district $\left(\mathrm{t}-10{ }^{\circ} \mathrm{C}, \mathrm{pH}=6.03\right.$, oxygen dissolved in water $\left.6.34 \mathrm{mg} / \mathrm{l}\right)$, r. Zherov near v. Zakoosyly, and r. Kamenka near v. Kalynivka of Narodychi district ( $\mathrm{t}$ of water $-18{ }^{\circ} \mathrm{C}, \mathrm{pH}=6.18$, oxygen dissolved in water $6.50 \mathrm{mg} / \mathrm{l}$ and $\mathrm{t}$ of water $11{ }^{\circ} \mathrm{C}, \mathrm{pH}=6.18$, oxygen dissolved in water $5.50 \mathrm{mg} / \mathrm{l}$, respectively), r. Bystrovka near v. Pylypovychi of Radomyshl district ( $\mathrm{t}$ of water $-22{ }^{\circ} \mathrm{C}, \mathrm{pH}=6.27$, oxygen dissolved in water $6.63 \mathrm{mg} / \mathrm{l}$ ).

Genus Korotnevella (Page, 1981) Goodkov, 1988

Locomotor forms of all known Korotnevella species belong to the same, very characteristic, dactylopodial morphotype. These amoebae generally form few finger-like hyaline subseudopodia almost of the same length produced from the frontal and fronto-lateral zone of hyaline cytoplasm. Floating specimens normally have distinct spherical central cell mass with radiating thin pseudopodia; amoeba mononuclear. The most characteristic ultrastructural feature of this genus is laced scales in cell cover. Three freshwater species of the genus are known (Smirnov, Brown, 2004; Smirnov, 2008).

\section{Korotnevella sp. (fig. 3)}

Among all freshwater representatives of the subclass Gymnamoebia, only the species from the genus Korotnevella have dactylopodial morphotype. The organism described in locomotion had very distinctive morphodynamic cell organization typical for dactylopodial morphotype.

Amoebae form hyaline dactylopodia on the front end of the cell body (2 to 6 ). Dactylopodia are typical for Korotnevella in shape and relatively equal in length. There is wide frontal-lateral zone of hyaline cytoplasm. One contractile vacuole is often located in the middle of the cell or closer to the posterior end of body. No morphological uroid structures were found. Length of moving amoeba is $15-25 \mu \mathrm{m}$, width is
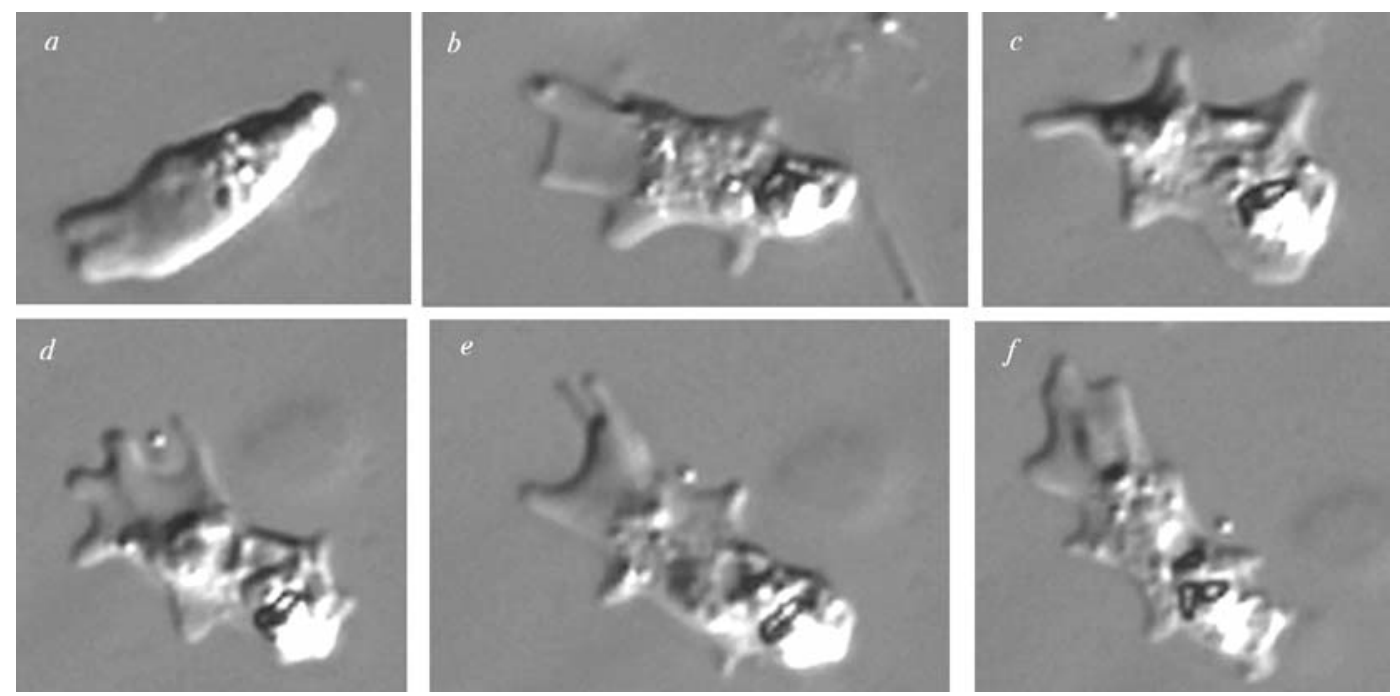

Fig. 3. Korotnevella sp., locomotor forms ( $a, b, c, d, e, f)$. x1240.

Pис. 3. Korotnevella sp., локомоторные формы ( $a, b, c, d, e, f)$. х1240. 
$8-15 \mu \mathrm{m}, \mathrm{L} / \mathrm{B}$ ratio $-1.8-2.0$. One nucleus is located closer to zone of hyaline cytoplasm in the anterior end; its diameter is less than $3 \mu \mathrm{m}$.

The organism found is very similar to one of three known species of freshwater Korotnevella, namely K. diskophora (Smirnov, 1999), but its identification needs some additional ultrastructural studies of the cell cover.

Location: this species was found in a lake near v. Guta-Zabilotska of Radomyshl district ( $\mathrm{t}$ of water $-13{ }^{\circ} \mathrm{C}, \mathrm{pH}=6.84$, oxygen dissolved in water $5.73 \mathrm{mg} / \mathrm{l}$ ).

Genus Paradermamoeba Smirnov et Goodkov, 1993

Locomotor forms of amoebae from this genus are of characteristic lanceolate morphotype. These are elongated lanceolate cells, tapering off to anterior and posterior ends of the body. The side cytoplasmic areas are strongly spread on substrate forming narrow lobes sometimes entirely consisting of hyaline cytoplasm, and stretching along the sides of amoeba's body with maximum width in its middle. The body length to width ratio is normally greater than 2.8 when moving. During locomotion, discrete pseudopodia are not formed. At the front end of the body there is frontal zone of hyaloplasm passing into peripheral hyaline part of lateral lobes. No folds or scallops on dorsal surface of amoeba's body are present. The characteristic ultrastructural feature of Paradermamoeba is a complicated supermembranous plasmalemmal complex looking as tightly packed spiral glycostiles with hollow processes, pentagonal in cross-section, on the upper tip (Smirnov, Goodkov, 1993; Smirnov, Goodkov, 1994). Only 2 freshwater species: P. valamo Smirnov et Goodkov, 1993 (Smirnov, Goodkov, 1993) and P. levis Smirnov et Goodkov, 1994 (Smirnov, Goodkov, 1994) were described in this genus.

\section{P. levis Smirnov et Goodkov, 1994 (fig. 4)}

An organism found had set of features characteristic for P. levis. The morphotype is lanceolate, specific lateral lobes are long, narrow, while moving they can be partially reduced. The length of locomotor specimens is $25-43 \mu \mathrm{m}$, width is $7-16 \mu \mathrm{m}, \mathrm{L} / \mathrm{B}$ ratio $-3.2-3.4$. One vesicular nucleus is $2-3.5 \mu \mathrm{m}$ in diameter.

Location: this species was found in lakes with sandy bottom near v. Lyudvynivka of Ovruch district ( $\mathrm{t}$ of water $-20^{\circ} \mathrm{C}, \mathrm{pH}=7.68$, oxygen dissolved in water $8.02 \mathrm{mg} / \mathrm{l}$ ), v. Chernyavka of Krasnoarmeyskiy district ( $\mathrm{t}$ of water $-14{ }^{\circ} \mathrm{C}, \mathrm{pH}=8.62$, oxygen dissolved in water $8.06 \mathrm{mg} / \mathrm{l}$ ).

\section{P. valamo Smirnov et Goodkov, 1993 (fig. 5)}

Morphotype is lanceolate. The lateral parts of hyaline zone as flattened lobes are spread on substrate and cover amoeba almost along its whole body. Length of amoeba reaches $45-75 \mu \mathrm{m}$, width $14-23 \mu \mathrm{m}, \mathrm{L} / \mathrm{B}$ ratio $-2.5-2.8$. One vesicular nucleus is about $6.4 \mu \mathrm{m}$ in diameter, the only endosome lies centrally.

Location: this organism was found in lakes with sandy bottom near v. Lyudvynivka of Ovruch district ( $\mathrm{t}$ of water $-20^{\circ} \mathrm{C}, \mathrm{pH}=7.68$, oxygen dissolved in water $8.02 \mathrm{mg} / \mathrm{l}$ ),

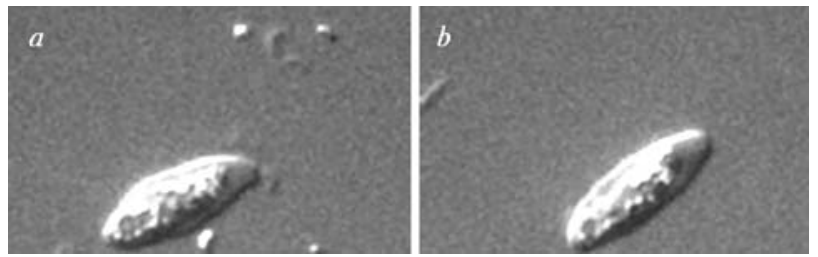

Fig. 4. Paradermamoeba levis, locomotor forms $(a, b)$. x1240.

Рис. 4. Paradermamoeba levis, локомоторные формы ( $a, b)$. х1240. 

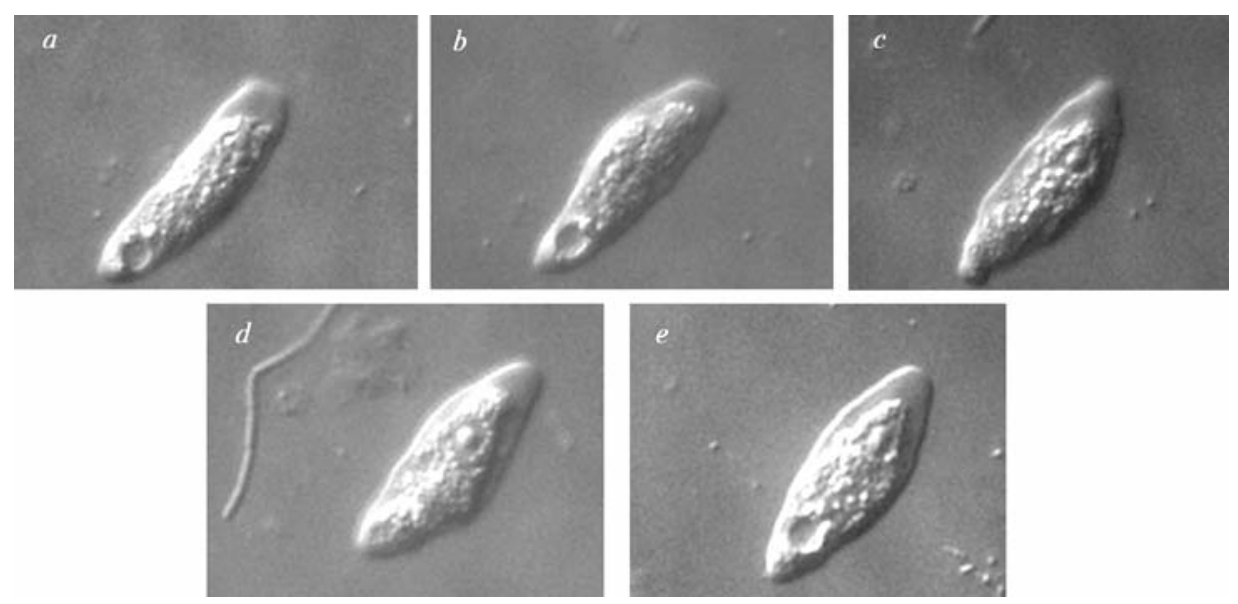

Fig. 5. Paradermamoeba valamo, locomotor forms ( $a, b, c, d, e) . \times 1240$.

Рис. 5. Paradermamoeba valamo, локомоторные формы ( $a, b, c, d, e)$ х1240.
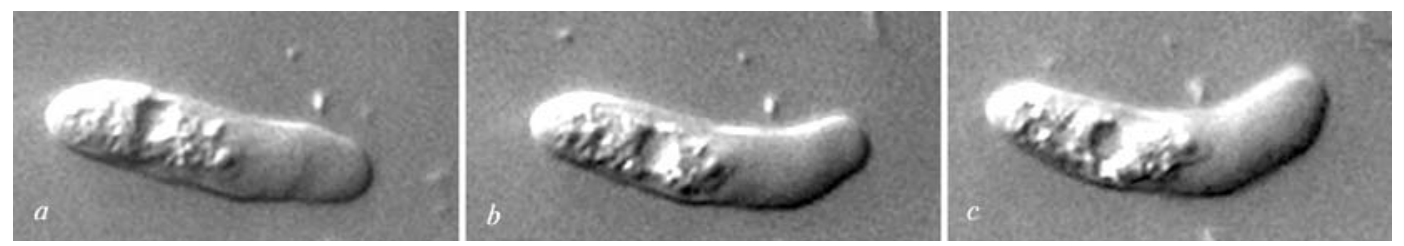

Fig. 6. Stenamoeba stenopodia, locomotor forms $(a, b, c) . \times 1240$.

Рис. 6. Stenamoeba stenopodia, локомоторные формы $(a, b, c)$. х1240.

v. Chernyavka of Krasnoarmeyskiy district ( $\mathrm{t}$ of water $-14{ }^{\circ} \mathrm{C}, \mathrm{pH}=8.62$, oxygen dissolved in water $8.06 \mathrm{mg} / \mathrm{l}$ ).

Genus Stenamoeba Smirnov, Nassonova, Chao et Cavalier-Smith, 2007

Monotypic genus.

S. stenopodia Smirnov, Nassonova, Chao et Cavalier-Smith, 2007 (fig. 6)

Locomotor forms of amoebae found are of typical lingulate morphotype. Amoebae are oval, elongated, with smoothly outlined body. The body length is significantly larger than width $(\mathrm{L} / \mathrm{B}=2.0-2.5)$. The frontal zone of hyaline cytoplasm may reach up to $2 / 3$ of amoeba's cell length. Morphologically differentiated uroid is absent. The body length is $16-28 \mu \mathrm{m}$, width is $8-10 \mu \mathrm{m}$. One nucleus is $2.0-3.8 \mu \mathrm{m}$ in diameter. By these characters the organism found can be identified as $S$. stenopodia.

Location: this organism was found in lakes with sandy bottom near v. c. Chernyavka of Krasnoarmeyskiy district ( $\mathrm{t}$ of water $-14{ }^{\circ} \mathrm{C}, \mathrm{pH}=8.62$, oxygen dissolved in water $8.06 \mathrm{mg} / \mathrm{l})$, v. Zamozhne of Zhytomyr district ( $\mathrm{t}$ of water $-17{ }^{\circ} \mathrm{C}$, $\mathrm{pH}=9.22$, oxygen dissolved in water $8.02 \mathrm{mg} / \mathrm{l}$ ).

All 6 species of gymnamoebae found in the present study are new both for Zhytomyr Polissya and for the fauna of Ukraine in general.

The author is grateful to Dr. A. Goodkov and Dr. A. Smirnov (St. Petersburg, Russia) for consultations on study methods and identification of gymnamoebae, as well as to Dr. V. A. Kharchenko (Institute of Zoology NAS of Ukraine) for assistance in work with microscope Zeiss Axio Imager M1.

Goodkov A. V., Buryakov V. Yu. Mayorella dactylifera sp. n. (Gymnamoebia, Paramoebidae) and an overview of marine Mayorella species // Zool. jorn. - 1987. - 67, N 6. - P. 927-931. - Russian : Гудков А. В., Буряков В. Ю. Mayorella dactylifera sp. n. (Gymnamoebia, Paramoebidae) и краткий обзор морских видов майорелл. 
Butchinskiy P. N. Fauna of Odessa limans // Proc. Novorossiysk naturalists society. - 1897. - 21, iss. II. P. 1-85. - Russian : Бучинский П. Н. Фауна одесских лиманов.

Dobrovlyanskiy V. V. List of the freshwater protozoans in Kiev vicinity // Proc. Dnepr. biol. station. 1914. - N 1. - P. 35-47. - Russian : Добровлянский В. В. Список пресноводных простейших окрестностей г. Киева.

Fadeev $N$. N. Catalogue of water animals found in the basin of Donets river and surrounding areas during the period of works from 1917 to 1927 // Proc. Kharkov naturalists society -1929 . - N 52. P. 7-32. - Russian : Фадеев H. Н. Каталог водных животных, найденных в басейне р. Донца и прилегающих местностях за период работ с 1917 по 1927 г.

Krasheninnikov R. M. Materials to protozoan fauna in Zaspa lake and closest still waters (former Domaha lake) // Notes Kyiv vet.-zootech. inst. - 1925. - 3. - P. 38-42. - Ukrainian : Крашеннініков С. М. Матеріали до фауни Protozoa оз. Заспи та найблищих до цього озера стоячих водозборів (бувш. о3. Домаха).

Lepinis A. K., Geltser Yu. G., Chibisova O. I, Geptner V. A. Key to soil Protozoa in European part of the USSR. - Vilnius : Mintis, 1973. - 171 p. - Russian : Лепинис А. К., Гельцер Ю. Г., Чибисова О. И., Гептнер В. А. Определитель Protozoa почв европейской части СССР.

Page F. C. A new key to freshwater and soil gymnamoebae // Freshwater Biological Association, Ambleside, Cumbria, UK. - 1988. - P. 122.

Patsuyk M. K. Lobose gymnamoebae (Lobozea, Gymnamoebia) from some water bodies of Radomyshl vicinity // Sci. notes Gnatyuk Ternopil teachers univ. Ser: Biology. Spec. iss.: Hydroecology. — 2010. N 2 (43). - P. 390-395. - Ukrainian : Пацюк M. К. Голі лобозні амеби (Lobozea, Gymnamoebia) деяких водойм околиць м. Радомишль.

Pereyaslavtseva R. M. Protozoa from the Black Sea. - Odessa : Odesskiy vestnik, 1886. - 16 p. - Russian Переяславцева С. М. Protozoa Черного моря.

Smirnov A. V. Korotnevella diskophora n. sp. (Gymnamoebia, Paradermoebidae) - small freshwater amoeba with peculiar scales // Protistology. - 1999. - 1. - P. 30-33.

Smirnov A. Amoebas, Lobose // Encyclopedia of Microbiology / Ed. M. Schaechter. - Oxford : Elsevier, 2008. - P. 558-577.

Smirnov A. V., Goodkov A. V. Paradermamoeba valamo gen. n., sp. n. (Gymnamoebia, Thecamoebidae) freshwater amoeba from bottom soil // Zool. jorn. - 1993. - 72, N 2. - P. 5-11. - Russian : Смирнов А. В., Гудков А. В. Paradermamoeba valamo gen. n., sp. n. (Gymnamoebia, Thecamoebidae ) - пресноводная амёба из донного грунта.

Smirnov A. $V$., Goodkov A. $V$. Freshwater Gymnamoebae with a new type of surface structure Paradermamoeba valamo and P. levis n. sp. (Thecamoebidae), and notes on the diagnosis of the family // Acta Protozool. - 1994. - 33. - P. 109-115.

Smirnov A., Goodkov A. An illustrated list of basic morphotypes of Gymnamoebia (Rhizopoda, Lobosea) // Protistology. - 1999. - 1. - P. 20-29.

Smirnov A., Brown S. Guide to the methods of study and identification of soil gymnamoebae // Protistology. - 2004. - 3. - P. 148-190.

Smirnov A., Nassonova E., Chao E., Cavalier-Smith T. Phylogeny, evolution and taxonomy of vannellid amoebae // Protist. - 2007. - 158. - P. 295-324.

Stepanov P. T. Fauna of Veisovo Lake // Proc. naturalists society at Kharkov Univ. - 1885. - 19. P. 1-31. - Russian : Степанов П. Т. Фауна Вейсова озера

Stroganov N. R., Buzinova N. R. Practice guidelines on hydrochemistry. - Moskow : MGU, 1980. 196 p. - Russian : Строганов Н. С., Бузинова Н. С. Практическое руководство по гидрохимии.

Vysotskiy $A . V$. Mastigophora and Rhizopoda found in Veis and Repne lakes // Proc. naturalists society at Kharkov Univ. - 1885. - 19. - P. 119-140. - Russian : Высоцкий A. В. Mastigophora и Rhizopoda, найденные в Вейсовом и Репном озерах. 